\title{
EVALUASI SOCIAL SUSTAINABILITY PADA FASILITAS PUBLIK STUDI KASUS: RPTRA BAHARI, GANDARIA SELATAN
}

\section{Eka Permanasari}

Universitas Pembangunan Jaya

eka.permanasari@upj.ac.id

\author{
Sahid \\ Universitas Pembangunan Jaya \\ sahid@upj.ac.id \\ Rahma Purisari \\ Universitas Pembangunan Jaya \\ rahma.purisari@upj.ac.id
}

\begin{abstract}
Abstrak
Upaya membantu masyarakat dalam memiliki ruang terbuka untuk berinteraksi dan berkegiatan di ruang kota seringkali mengarah pada pembangunan fisik dalam bentuk infrastruktur yang hanya mengakomodasi agenda pemerintah. Akibatnya, pengembangan ini lebih cenderung kepada bentukan fisik dan melupakan siapa penggunanya. Meskipun fasilitas dan infrastruktur ini dibuat untuk memenuhi kebutuhan masyarakat, seringkali setelah bangunan fisik terbangun, keberkelanjutan kegiatan tidak terjadi disana. Tidak adanya partisipasi masyarakat dalam proses desain adalah salah satu penyebab kurangnya rasa memiliki terhadap fasilitas yang ada. Penelitian ini mengevaluasi keberlanjutan sosial Ruang Publik Terpadu Ramah Anak-RPTRA Bahari, Gandaria Selatan, Jakarta, melalui pengukuran terhadap rasa memiliki masyarakat sekitar. Penelitian ini menggunakan metode kuantitatif untuk mengetahui seberapa besar rasa memiliki masyarakat terhadap fasilitas publik di lingkungan mereka. Hasilnya menunjukkan variasi tingkat rasa memiliki atas fasilitas tersebut namun sebagian besar masyarakat merasakan kemanfaatannya. Dapat disimpulkan bahwa secara sosial, RPTRA Gandaria dinilai "sustainable" karena masyarakat tidak hanya mengenal RPTRA, tetapi memanfaatkan sekaligus turut terlibat dalam menjaga kelangsungannya di masa depan.
\end{abstract}

Kata-kata Kunci: Keberlanjutan Sosial, Fasilitas Publik, RPTRA Bahari

\section{EVALUATING SOCIAL SUSTAINABILITY IN PUBLIC FACILITIES CASE STUDY: RPTRA BAHARI, GANDARIA SELATAN}

\footnotetext{
Abstract

Efforts to help people have open spaces for interaction and activities in urban area often lead to physical development in infrastructure that only accommodates the government agenda. As a 
result, this development prefers physical form and forgets who the user will be. Although these facilities and infrastructure are made to meet the needs of the community, often after the physical building is built, there is no sustainable activity taking place there. The exclusion of community participation in the design process is one of the causes of the lack of sense of belonging to the facilities built. This paper evaluates the social sustainability of the Bahari Child-Friendly Public Space (Ruang Publik Terpadu Ramah Anak-RPTRA) in South Gandaria, Jakarta, through measuring the sense of belonging of the surrounding community. This study uses quantitative methods to determine how much the community sense of belonging to public facilities in their environment. The results show a variety of sense of belonging level, and most of the community feel the benefits of the RPTRA facility. It can be concluded that the RPTRA Gandaria is socially "sustainable" because the community is not only familiar with the building but also utilizes and is involved in maintain its sustainability in the future.

Keywords: Social Sustainability, Public Facilities, RPTRA Bahari

\section{Pendahuluan}

RPTRA (Ruang Publik Ramah Anak) Bahari, Gandaria Selatan merupakan salah satu ruang publik yang ditetapkan oleh Pemerintah Provinsi DKI Jakarta dalam upayanya melindungi hak anak untuk tumbuh dan bersosialisasi dalam lingkungan yang baik. RPRTA ini diinisiasi dengan proses berkelanjutan dan merupakan hasil kolaborasi antara pemerintah, tim sosial, perancang dengan pemeran utamanya adalah masyarakat Kelurahan Gandaria Selatan. Prosesnya sangat menarik karena menggunakan metode atau pendekatan desain partisipatif, dimana masyarakat dilibatkan secara langsung dalam setiap tahap perencanaan hingga pembangunannya. Hal ini menunjukkan bahwa seluruh stakeholder memikirkan bagaimana sebuah proses dan hasil merupakan satu rangkaian yang tak terpisahkan.

Pada awalnya program ini akan dilaksanakan dengan pendekatan dari atas (top-down approach). Namun beberapa pihak mengingatkan bahwa jika tetap menggunakan pendekatan topdown maka dikhawatirkan program ini tidak akan berbeda dengan program-program sebelumnya dan bahkan dikhawatirkan tidak akan berkelanjutan (sustainable) karena penelitian Jones, Petrescu \& Till (2012) menunjukkan bahwa pendekatan tersebut akan berdampak pada kurangnya rasa memiliki terhadap ruang publik yang tercipta (Jones, Petrescu, \& Till, 2012). Pemerintah Provinsi DKI Jakarta menyadari bahwa banyak ruang publik telah beralih fungsi dan terbengkalai setelah dibangun karena pendekatan top down yang telah dilakukan sebelumnya. Guna mengatasi hal tersebut Pemerintah Provinsi DKI Jakarta bekerjasama dengan sosiolog dan Urban Designer berusaha seoptimal mungkin untuk melibatkan masyarakat dalam proses social mapping, pembangunan serta pengelolaan RPTRA di Kelurahan Gandaria Selatan (Elyda \& Budiari, 2015). Sosiolog yang terlibat dalam tahapan sosialisasi, social mapping, perancangan, pembangunan dan pengelolaan adalah Bapak Imam Prasodjo dari Universitas Indonesia. Salah satu hal yang dianggap sebagai kekurangan pendekatan bottom-up adalah lamanya proses yang dibutuhkan untuk mendapatkan kesepakatan dari semua pihak. Kebalikannya, pendekatan top down memiliki kelebihan dalam kecepatan waktu implementasi. Nampaknya, kombinasi antara pendekatan top-down dan bottom-up dalam membangun ruang publik perlu dilakukan untuk memfasilitasi kepentingan pemerintah dan masyarakat. Proses desain bottom-up yang melibatkan pengguna (dalam hal ini masyarakat) sering disebut sebagai pendekatan desain partisipatif.

Pembangunan RPTRA Bahari telah mengikuti 6 langkah pendekatan desain partisipatif dalam desain, yaitu: melakukan pemetaan sosial, mengadakan diskusi tentang desain awal, desain akhir, bekerja sama dalam membangun RPTRA dengan cara menandatangani pakta integritas dan membangun secara gotong royong, serta secara bersama-sama mendiskusikan tentang manajemen 
RPTRA. Seluruh proses membutuhkan waktu lebih kurang 6 (enam) bulan. Kegitan pemetaan sosial dimulai ketika arsitek, perancang kota, dan peneliti sosial secara bersama mencoba menggambarkan kondisi eksisting di lokasi yang akan dibangun RPTRA. Langkah selanjutnya adalah merancang konsep desain dengan melibatkan masyarakat dalam proses desain partisipatif. Arsitek, perancang kota dan sosiolog mengusulkan ide pusat komunitas untuk memenuhi kebutuhan anak-anak dengan kegiatan positif. Daerah Gandaria Selatan merupakan kawasan padat penduduk dan sekaligus padat bangunan, satu-satunya opsi lahan untuk RPTRA adalah lahan milik pemerintah seluas $926 \mathrm{~m}^{2}$. Achmad Noerzaman, selaku Arsitek, menjelaskan tujuan didirikannya RPTRA dan bagaimana cara meujudkannya. Perwakilan masyarakat setempat diberikan kebebasan untuk memberikan umpan balik tentang jenis kegiatan yang mereka butuhkan atau impikan. Arsitek, perancang kota dan peneliti sosial berperan sebagai mediator yang menghubungkan dua kepentingan yaitu warga dan pemerintah. Metode partisipasi ini memberikan kesempatan bagi kedua belah pihak yaitu perwakilan pemerintah dan perwakilan warga untuk secara terbuka berbicara dan mengusulkan ide-ide mereka.

Upaya melibatkan masyarakat dalam proses perencanaan dan pembangunan RPTRA ini bermanfaat untuk menumbuhkan keterikatan masyarakat dengan fasilitas RPTRA. Indikator keberhasilan proses partisipasi desain tersebut tampak hingga saat ini setelah 4 tahun RPTRA berdiri. Kegiatan yang direncanakan terus berjalan dan tumbuh atas pemberdayaan masyarakat, meskipun beberapa bagiannya sempat vakum karena kendala tertentu. Upaya untuk terus melibatkan masyarakat hingga pada tahap pengelolaan bangunan dan kegiatan tetap dilakukan untuk mendorong keberlanjutan RPTRA. Untuk mengetahui keberlanjutan RPTRA di masa depan, salah satunya dapat diketahui dengan cara melakukan identifikasi atas kepedulian masyarakat terhadap kehadiran RPTRA di lingkungan mereka. Identifikasi dimulai dengan menanyakan pengetahuan masyarakat tentang kondisi fisik RPTRA (bangunan dan fasilitas), kemudian menanyakan pengetahuan masyarakat tentang kegiatan yang berlangsung di RPTRA (jenis kegiatan, jadwal dan frekuensi penggunaan) serta menanyakan kemauan masyarakat untuk terlibat dalam mengikuti kegiatan (user), menginisiasi kegiataan (inisiator), menjadi fasilitator (kontributor) dan bahkan turut merawat kondisi fisik RPTRA.

Selain memiliki kemampuan untuk terhubung dengan sesama, manusia juga dapat terhubung dengan lingkungan sekitarnya. Beberapa istilah untuk menggambarkan hubungan antara manusia dan lingkungan adalah sense of belonging dan place attachment. Beberapa peneliti menyebutkan rasa memiliki sebagai kebutuhan esensial bagi individu, keluarga, dan komunitas (Hill, 2006). Sedemikian pentingnya sehingga ungkapan rasa memiliki ini sering disebutkan dalam berbagai bidang studi. Rasa memiliki dapat diartikan sebagai pengalaman pribadi seseorang ketika terlibat dengan lingkungan sehingga orang yang bersangkutan merasa terikat dengan lingkungan (Hill, 2006) dan (Hagerty, Williams, \& Oe, 2002). Lebih lanjut, place attachment merupakan rasa keterikatan, keterhubungan, atau keterikatan antara seseorang dan lingkungannya. Para peneliti sering menggunakan The Tripartite Model (Gambar 1) yang diungkapkan oleh Scannel dan Gifford (2010) untuk menjelaskan fenomena place attachment yang dimaksud. Model ini menjelaskan tiga dimensi yang berperan dalam pembentukan place attachment, yaitu person (aktor), place (tempat), dan process (proses). Pada sisi aktor, model ini tidak hanya berlaku untuk individu tetapi juga berlaku untuk kelompok orang, pada sisi tempat, model ini bisa bersifat fisik dan sosial, sementara di sisi proses model ini mempertimbangkan peran kasih sayang, kognisi dan perilaku dalam membentuk emosi untuk melewatkan tempat. 


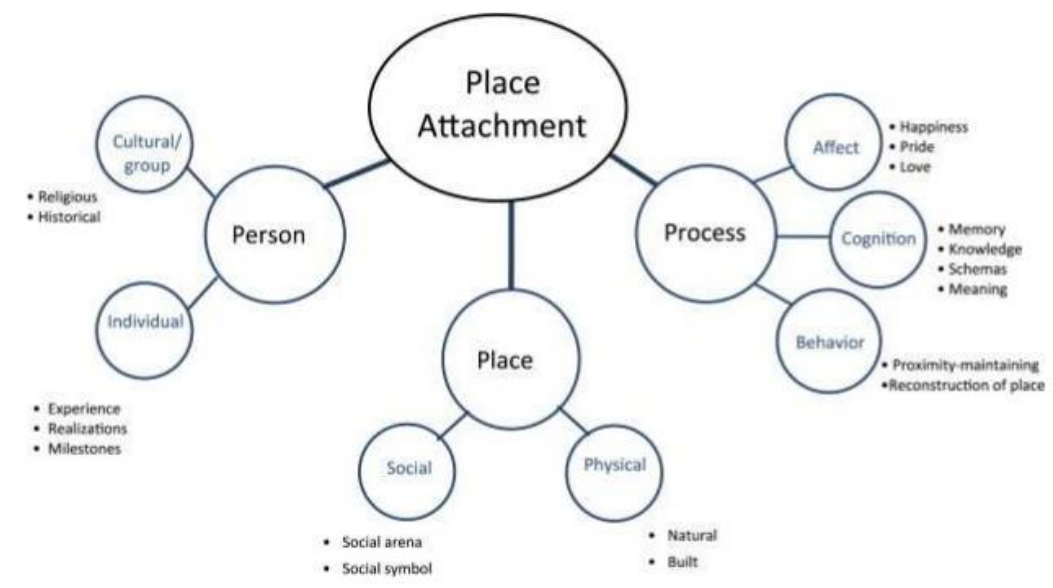

Gambar 1. The Tripartite Model of Place Attachment Sumber: Scannell dan Gifford, 2010

Perasaan keterikatan pada suatu tempat atau sering juga disebut sebagai kelekatan kepada suatu tempat (place attachment) bisa digambarkan sebagai perasaan berada di rumah atau perasaan memiliki atas suatu tempat (Ernawati, 2017). Keterikatan seseorang pada suatu tempat sering kali tercermin pada perilaku berdasarkan pengalaman yang telah dilalui sebelumnya (Bruntland \& Gro, 1987). Kecenderungan untuk kembali hadir di tempat tertentu dan mengulang peristiwa tertentu yang dianggap bermakna merupakan bagian dari kelekatan seseorang pada suatu tempat. Keinginan untuk hadir di suatu tempat ini terkadang terjadi tanpa sadar sebagai bagian dari pengalaman positif yang dialami oleh seseorang atau sekelompok orang pada suatu lingkungan fisik (Nurhijrah, 2015). Kelekatan seseorang pada suatu tempat bervariasi tergantung interaksi antar keduanya dan kelekatan ini juga tumbuh beriringan dengan waktu sesuai interaksi antara antara keduanya (Nurhijrah, 2015). Variasi kelekatan inilah yang kemudian diusulkan untuk diukur melalui ingatan (pengetahuan) sebagai representasi dari kelekatan yang paling rendah, kehadiran sebagai representasi kelekatan tingkat menengah dan keterlibatan sebagai representasi kelekatan tingkat paling tinggi.

Di sisi lain, sustainability menyangkut tiga komponen utama yaitu: environment, social, economy (Bruntland \& Gro, 1987). Social sustainability pada penelitian ini didefinisikan sebagai tingkat keberlanjutan sebuah fasilitas ruang publik ditinjau dari segi dukungan masyarakat sekitarnya. Dukungan tersebut tercermin dalam kedekatan (place attachment/senses of belonging/bound to the environment) masyarakat pada fasilitas publik tersebut. Karenanya, social sustainability akan diukur dari kedekatan atau keterlibatan masyarakat sekitar ruang publik baik dalam mengenali secara detil fasilitasnya (ingatan/pengetahuan), frekuensi penggunaan serta kepedulian untuk turut serta sebagai kontibutor maupun inisiator untuk kelangsungan ruang publik tersebut (Gambar 2). Pada akhirnya, hasil dari penelitian ini diharapkan dapat memberikan kontribusi sebagai bahan evaluasi dan masukkan bagi stakeholder dalam membangun RPTRA. 


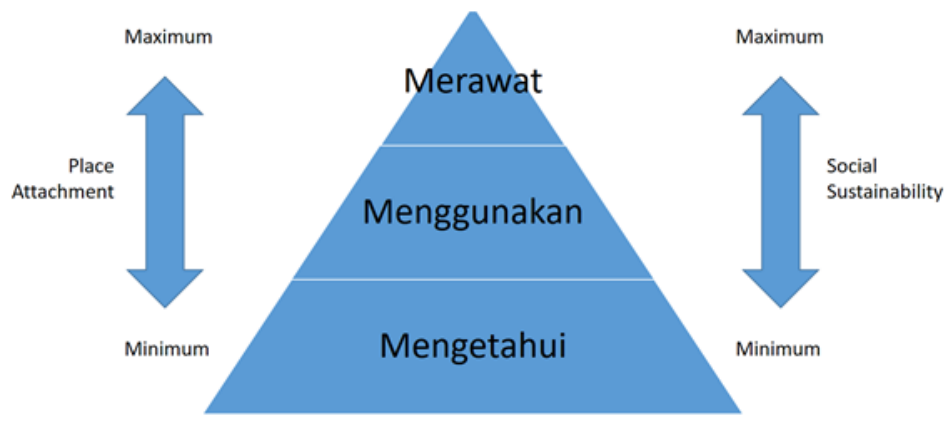

Gambar 2. Interpretasi Hubungan Antara Place Attachment, Social Sustianability Dan Sikap Masyarakat Atas RPTRA

Sumber: Olahan Peneliti, 2020

Beberapa penelitian sejenis yang membahas tentang implementasi place attachment diantaranya adalah penelitian Nurhijrah (2015), diantaranya (1) Kerangka Penelitian Place Attachment pada Tempat Bernilai Budaya, dan (2) Place Attachment Masyarakat Tana Luwu pada Ruang Publik Dekker, bahwa faktor non fisik (interaksi sosial) berpengaruh terhadap terbentuknya rasa keterikatan atau kelekatan pada suatu terhadap tempat. Adapun faktor yang mempengaruhi keterikatan pada tempat ialah manusia (demografis) dan tempat (karakeristik fisik, nilai dan makna historis, aktivitas yang terjadi, lokasi). Penelitian Jenny Ernawati yang membagi tiga dimensi atau faktor yang mendasari evaluasi masyarakat terhadap place identity yaitu Hubungan Personal, Lingkungan Fisik, dan Komitmen (Ernawati, 2017). Ketiga dimensi evaluatif place identity tersebut menjelaskan sebagian besar keberagaman yang terdapat di masyarakat. Selanjutnya Penelitian Mas Muhammad Hizbullah Sesunan merangkum indikator place attachment yang mempengaruhi keberhasilan sebuah ruang publik, yaitu dimensi manusia, dimensi aktivitas dan dimensi physical setting-nya (Sesunan, 2014). Dimensi manusia berkaitan dengan makna tempat tersebut untuk masyarakat, tingkat kenyamanannya serta karakter penggunanya. Dimensi aktivitas berkaitan dengan keragaman kegiatan di dalam ruang publik. Sedangkan dimensi physical setting berkaitan dengan desaian ruang publik tersebut (Sesunan, 2014). Dapat disimpulkan bahwa kelekatan seseorang terhadap ruang publik bergantung pada seberapa besar ruang publik tersebut dapat mengakomodasi kebutuhan penggunanya. Semakin dibutuhkan maka pengguna akan semakin sering menggunakan ruang tersebut dan selanjutnya tumbuh rasa memiliki untuk turut mempertahankan keberlanjutannya secara sosial (social sustainability).

\section{Metode}

Penelitian ini bergerak dari pemikiran bahwa social sustainability dapat diukur dari place attachment/sense of belonging masyarakat pada RPTRA. Untuk mengetahui keterikatan tempat/rasa memiliki masyarakat di sekitar fasilitas Ruang Publik Ramah Anak (RPTRA) Bahari, peneliti menggunakan metode kuantitatif. Data diperoleh melalui kuesioner yang disebar secara acak kepada masyarakat (130 responden) yang tinggal di sekitar RPTRA Bahari dengan radius maksimum 800 meter. Penyebaran kuesioner dilakukan untuk mendapatkan data mengenai karakteristik pengunjung RPTRA, pengetahuan mereka tentang fasilitas yang ada, jenis kegiatan yang diselenggarakan, jadwal dan frekuensi kegiatan di RPTRA dan keterlibatan mereka dalam menggunakan, mengisi kegiatan dan merawat fasilitas. Data-data tersebut diharapkan dapat menjawab pertanyaan place attachment atau sense of belonging masyarakat terhadap fasilitas publik. Pengisian data dilakukan pada periode bulan Juni 2019 hingga Oktober 2019.

Kuesioner terbagi adalam 3 kelompok pertanyaan, kelompok pertama dibuat untuk mengetahui seberapa jauh pengetahuan masyarakat terhadap faslitas RPTRA yang telah tersedia di lingkungan 
mereka. Pertanyaan pada kelompok pertama ini juga terbagi menjadi tiga bagian. Pertama tentang pengetahuan tentang kondisi fisik RPTRA yang secara langsung bisa terlihat dari luar area RPTRA bahkan tanpa memasukinya, kedua tentang kegiatan (jadwal maupun acara) yang rutin dilaksanakan disana serta ketiga tentang peralatan yang tersedia di dalam bangunan. Semakin banyak yang diketahui responden maka diasumsikan bahwa responden semakin terlibat dalam kegiatan RPTRA atau danggap memiliki semakin memiliki kedekatan dengan RPTRA. Untuk kelompok pertama ini, hasil analisis kami kelompokkan dalam 5 kategori yaitu sangat kurang apabila pertanyaan yang benar terjawab kurang dari $40 \%$, kategori kurang apabila jawaban benar berkisar antara berkisar antara $40 \%$ hingga $50 \%$, cukup apabila jawaban bersinar antara $50 \%$ hingga $60 \%$, baik apabila jaaban berkisar antara $60 \%$ hingga $70 \%$ dan baik sekali apabila jawaban benar lebih dari $70 \%$.

Kelompok kuesioner kedua dibuat untuk mengetahui keaktifan responden sebagai pengguna RPTRA yang ditunjukkan dengan frekuensi kedatangan mereka di RPTRA. Pada kelompok kedua ini jaaban juga kami kategorikan dalam 5 kategori yaitu sangat kurang apabila frekuensi responden menyatakan tidak pernah, kategori kurang responden berkunjung maksimal 6 kali setahun, kategori cukup apabila responden datang 1-2 kali sebulan, kategori baik apabila responden datang 3-4 kali sebulan. Responden juga dtanyakan tentang kegiatan yang mereka lakukan saat datang di RPTRA. Kelompok kuesioner ketiga dibuat untuk mengetahui keterlibatan kesediaan responden terlibat lebih dalam tidak hanya sebagai pengunjung tapi sebagai pelaksana atau bahkan yang menginisiasi kegiatan di RPTRA. Responden juga diminta untuk mengusulkan kegiatan yang perlu diakomodir agar RPTRA dapat bermanfaat banyak bagi masyarakat sekitarnya.

\section{Hasil dan Pembahasan}

Hasil kuesioner memperlihatkan bahwa ada beberapa kategori yang berkaitan dengan hubungan antara masyarakat dan fasilitas publik yang tersedia di lingkungan mereka. Pertama adalah kelompok orang yang tidak peduli terhadap fasilitas umum yang tersedia, kedua adalah kelompok orang-orang yang peduli dengan fasilitas publik yang ditunjukkan dengan kesediaan untuk terlibat sebagai pengguna dengan intensitas penggunaan yang bervariasi, sedangkan yang ketiga adalah mereka yang sangat peduli dengan fasilitas umum di sekitarnya yang ditunjukkan oleh pemahaman tentang fasilitas, seringnya interaksi dan kemauan untuk terlibat dalam merawat dan bertindak sebagai penggagas dan fasilitator dari berbagai program kerja di fasilitas publik ini.

Peneliti menyebarkan kuesioner untuk mengetahui pengetahuan masyarakat tentang RPTRA yang berdiri di lingkungan mereka. Kuesioner dilakukan secara acak dan melibatkan 130 responden. Terdapat tiga kategori pertanyaan yang diberikan untuk mengevaluasi pengetahuan masyarakat tentang keberadaan fasilitas, mengevaluasi frekuensi penggunaan/keterlibatan sebagai pengguna, dan mengevaluasi keterlibatan masyarakat sebagai subjek pada RPTRA Gandaria Selatan. Untuk kategori pertanyaan dalam mengevaluasi pengetahuan masyarakat, peneliti mengajukan 11 pertanyaan, antara lain tentang ada atau tidaknya fasilitas, bagaimana kondisi fisik (bangunan) dan peralatan yang tersedia, serta kegiatan yang berlangsung di RPTRA

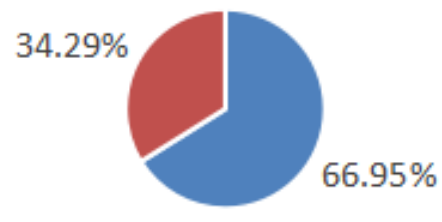

- Mengetahui $\boldsymbol{\|}$ Tidak mengetahui

Gambar 3. Evaluasi Pengetahuan Masyarakat Tentang Keberadaan Fasilitas Sumber: Olahan Peneliti, 2020 
Sesuai dengan Gambar 3, dari sejumlah 130 responden yang tersebar dalam radius 0-800 meter, sejumlah $66.95 \%$ menjawab pertanyaan kuisioner dengan benar sesuai dengan kondisi eksisting, sedangkan $34.29 \%$ sisanya tidak benar dalam menjawab pertanyaan atau dianggap tidak mengetahui kondisi yang sesungguhnya. Hal tersebut mengindikasikan bahwa sebagian besar masyarakat di sekitar RPTRA Gandaria Selatan mengetahui keberadaan fasilitas tersebut di lingkungan mereka. Hal ini juga mengindikasikan bahwa upaya sosialisasi yang dilakukan oleh RPTRA kepada masyarakat cukup berhasil. Hasil sebaran jawaban yang benar juga menunjukkan variasi tempat tinggal dari radius <100 meter hingga >500 meter. Hasil ini juga mengindikasikan bahwa radius tempat tinggal tidak terlalu mempengaruhi tingkat pengetahuan warga akan fasilitas di RPTRA Gandaria Selatan. Hal unik ditemukan bahwa responden yang bertempat tinggal >100 meter lebih banyak yang mengetahui atau menjawab dengan benar pertanyaan mengenai RPTRA Gandaria (kondisi bangunan dan fasilitasnya) daripada responden yang tinggal di radius <100 meter. Hal tersebut mengindikasikan bahwa beberapa warga yang berada sangat dekat dengan RPTRA masih ada yang belum mengetahui mengenai kegiatan dan fasilitas RPTRA.

Kategori kedua adalah untuk mengevaluasi frekuensi penggunaan/keterlibatan sebagai pengguna (Gambar 4). Kategori ini menunjukkan seberapa sering masyarakat menggunakan fasilitas RPTRA, baik dari kegiatan berkunjung maupun menggunakan fasilitas. Diagram tersebut menunjukkan bahwa persentase tertinggi kunjungan masyarakat adalah pada frekuensi 1-2 kali/ bulan, 1-3 kali/bulan, dan 3-4 kali/bulan (bervariasi dari 50\% hingga 93\%), baik dari warga yang berdomisili dari radius dekat maupun jauh. Tingkat kedua adalah pada frekuensi kunjungan setiap hari (bervariasi dari 7\% hingga 42\%) dan sisanya (bervariasi antara 4\% hingga 10\%) 2-6 kali/tahun tidak pernah, dan tidak menjawab. Beberapa hal unik ditemukan, diantaranya beberapa responden yang tinggal dalam radius kurang dari 100 meter jarang mengunjungi RPTRA bahkan beberapa diantaranya ada yang tidak pernah ke RPTRA. Sebaliknya, beberapa warga dalam radius lebih dari 500 meter justru lebih sering mengunjungi RPTRA. Hal yang menarik lainnya adalah pada tiap kategori radius, ternyata terdapat warga yang sama sekali tidak pernah mengunjungi RPTRA. Warga yang menjawab tidak pernah ini justru menunjukkan persentase yang rendah, dan hal ini mengindikasikan bahwa jarak/radius tidak menjamin warga untuk menggunakan fasilitas atau mengunjungi RPTRA.

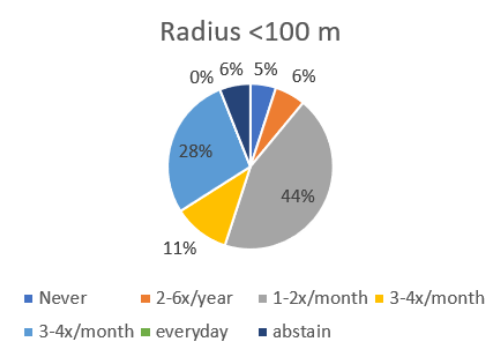

Radius 300-399 m

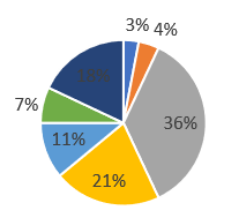

- Never $\quad=2-6 x /$ year $\quad=1-2 x /$ month $=3-4 x /$ month - $3-4 \mathrm{x} /$ month $=$ everyday $\quad$ abstain

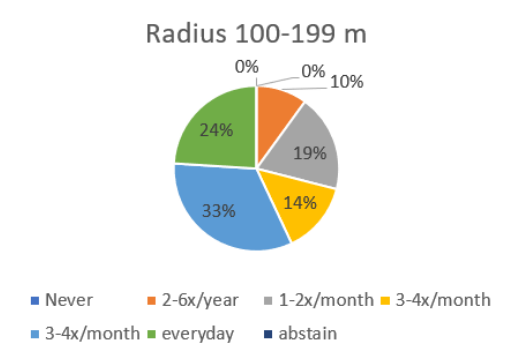

Radius 400-499 m

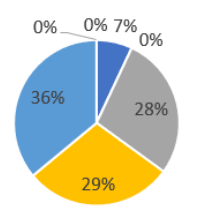

- Never $\quad$ - 2-6x/year $\quad=1-2 \mathrm{x} /$ month $\| 3-4 \mathrm{x} /$ month = $3-4 \mathrm{x} /$ month $=$ everyday $\quad$ - abstain

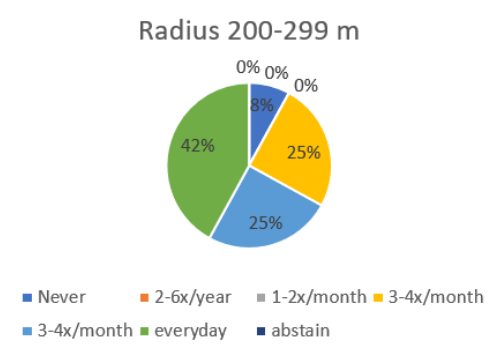

Radius $>500 \mathrm{~m}$

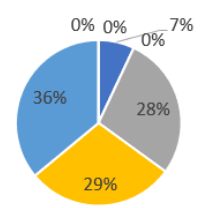

- Never $\quad=2-6 x /$ year $\quad 1-2 x /$ month $=3-4 x /$ month - 3-4x/month $=$ everyday $\quad$ - abstain

Gambar 4. Evaluasi Frekuensi Penggunaan/Keterlibatan Sebagai Pengguna

Sumber: Olahan Peneliti, 2020 
Kategori ketiga adalah untuk mengevaluasi keterlibatan masyarakat sebagai subjek (Gambar 5). Hasil jawaban warga yang diwawancarai, mayoritas mengindikasikan bahwa RPTRA Gandaria Selatan sampai saat ini masih diperlukan, karena dapat mengakomodasi kegiatan-kegiatan warga disana dan bahkan mereka bersedia untuk mengisi acara di RPTRA Gandaria. Ketika pertanyaan ini dimunculkan, masyarakat dengan radius <100 meter menunjukkan persentase tertinggi untuk terlibat dalam kegiatan dan penggunaan fasilitas RPTRA. Namun persentase ini tidak terlalu berbeda dengan masyarakat pada radius lainnya dan hanya sedikit warga yang menjawab tidak. Mayoritas responden bersedia untuk dilibatkan untuk merawat fasilitas RPTRA Gandaria
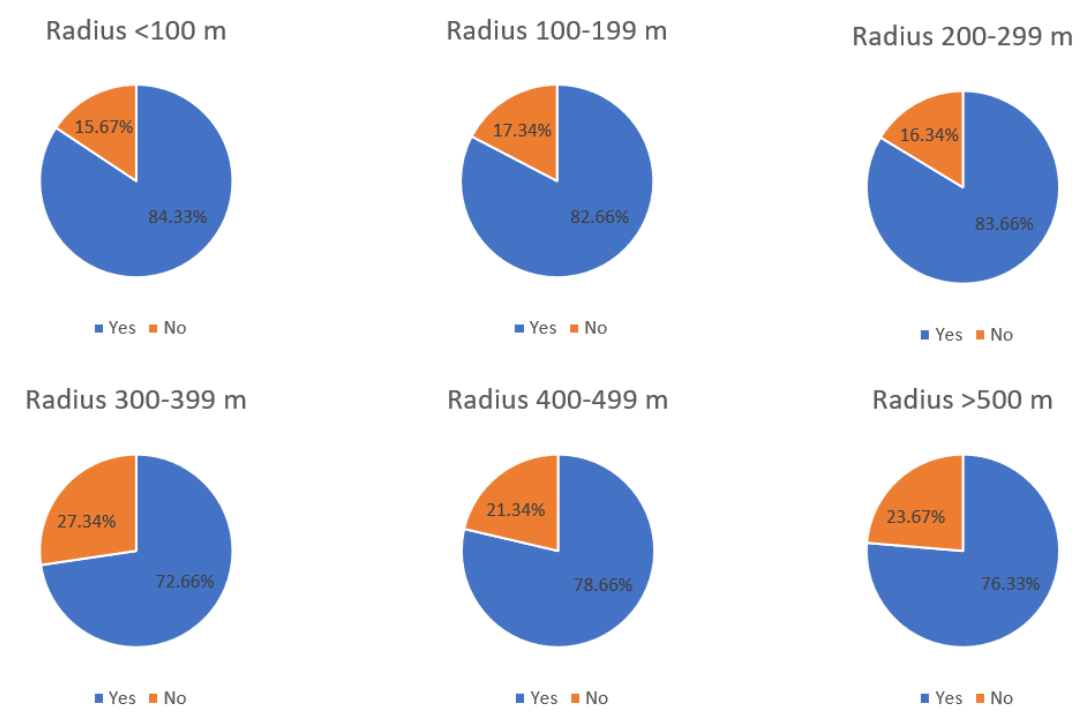

Gambar 5. Evaluasi Keterlibatan Masyarakat Sebagai Subjek Sumber: Olahan Peneliti, 2020

\section{Kesimpulan}

Hasil dari penelitian ini menunjukkan bahwa mayoritas warga di sekitar RPTRA hingga radius 500 meter sangat antusias oleh keberadaan RPTRA. Mayoritas warga mengetahui kondisi fisik, fasilitas yang tersedia di dalamnya, serta jam operasional RPTRA. Warga disana sangat peduli dan ingin berpartisipasi dalam membantu mengisi acara sesuai dengan kemampuan mereka. RPTRA Gandaria Selatan memiliki banyak fasilitas yang dapat digunakan seperti sarana olahraga, kegiatan belajar bersama dan dapat digunakan untuk hajatan, hal ini dapat menambah semangat warga untuk datang ke RPTRA. Warga yang datangpun bukan hanya untuk mengikuti kegiatan yang ada di RPTRA saja tetapi beberapa warga ada yang datang untuk bertemu dengan orang, berkesenian, dan sekedar berolahraga. Hal ini menunjukkan bahwa RPTRA Gandaria digunakan sebagai tempat bersosialisasi secara berkelanjutan antar warga tanpa harus terikat atau mengikuti kegiatan resmi di RPTRA.

Secara keseluruhan, kegiatan yang dicanangkan di RPTRA masih berjalan dengan baik. Sejauh ini kegiatan yang konsisten antara lain: futsal, senam, beragam les di perpustakaan dan angklung. Selebihnya, RPTRA lebih banyak berfungsi sebagai ruang publik yang digunakan bersama. Jika ditelisik lebih jauh, rasa kepemilikan masyarakat akan ruang publik sudah terwujud, namun levelnya perlu ditingkatkan. Hal ini terlihat dari kurangnya kesadaran masyarakat akan menjaga fasilitas serta memperbaiki fasilitas jika ada kerusakan. Meskipun masyarakat secara aktif berkegiatan di RPTRA dan rutin melakukan kerja bakti sebagai wujud dukungan mereka akan merawat ruang publik. Selain itu setiap elemen masyarakat juga bersedia untuk berkontribusi melakukan aktifitas sesuai dengan keahlian mereka. RPTRA Bahari, Gandaria Selatan akan berkelanjutan secara sosial karena sebagian besar masyarakat di sekitarnya memiliki place attachment yang tinggi, yang ditunjukkan dengan kehadiran masyarakat secara rutin, kesediaan untuk peduli dan terlibat aktif dalam kegiatan yang 
diadakan di dalamnya. Rasa memiliki ini hanya akan ada jika kebutuhan masyarakat akan fasilitas publik dapat dipenuhi.

\section{Ucapan Terima Kasih}

Terima kasih penulis sampaikan kepada Direktorat Riset dan Pengabdian Masyarakat, Direktorat Jenderal Penguatan Riset dan Pengembangan Kementerian Riset, Teknologi dan Pendidikan Tinggi (Kemenristek Dikti) yang telah memberikan Dana Hibah Penelitian Dasar dengan Nomor Kontrak 003/PER-P2M/UPJ-DIKTI/04.19. Selanjutnya terima kasih juga peneliti sampaikan kepada LP2M Universitas Pembangunan Jaya yang telah memberikan fasilitas untuk menyelenggarakan penelitian ini.

\section{Daftar Pustaka}

Bruntland, \& Gro, H. (1987). Report of the World Commission on Environment and Development: Our Common Future.

Elyda, C., \& Budiari, I. (2015, September 17). The Jakarta Post. Jakartans Enthusiased with New RPTRA Community Centers.

Ernawati, J. (2017). Faktor-faktor Pembentuk Identitas Suatu Tempat. Jurnal Local Wisdom, III(2).

Hagerty, B., Williams, R. A., \& Oe, H. (2002). Childhood Antecedents of Adult Sens of Belonging. Journal of Clinical Psychology, 58(7), 793-801.

Hill, D. (2006). Sense of Belonging as Connectedness. (A. I. Health, Ed.) 5(Archives of Psychiatric Nursing), pp. 210-216.
Jones, P., Petrescu, D., \& Till, J. (2012). Architecture and Participation. London and New York: Routledge.

Nurhijrah. (2015). Kerangka Penelitian Place Attachment pada Tempat Bernilai Budaya. Prosiding Temu Ilmiah IPLBI .

Nurhijrah. (2015). Place Attachment Masyarakat Tana Luwu pada Ruang Publik Dekker. Prosiding Seminar Arsitektur Nusantara 3.

Scannell, L., \& Gifford, R. (2010). Defining Place Attachment: A Tripartite Organizing Framework. Journal of Environmental Psychology, 30, 110.

Sesunan, M. M. (2014). Evaluasi Perwujudan Place Attachment pada Kawasan Revitalisasi Tepi Air Benteng Kuto Besak. E-Journal Graduate Unpar, 1(2). 